日顎変形誌 Jpn. J. Jaw Deform. 12 (3) : 94 102, December, 2002

\title{
朝日大学歯学部附属病院矯正歯科における 顎変形症に対する臨床統計学的観察
}

$\begin{array}{lllllllll}\text { 北 } & \text { 原 } & \text { 麻 } & \text { 紀 } & \text { 岸 } & \text { 本 } & \text { 正 雄 } & \text { 二井 敏 光 } \\ \text { 野 } & \text { 村 } & \text { 俊 } & \text { 弥 } & \text { 中 村 優 也 } & \text { 犬 束 信 一 } \\ \text { 日 } & \text { 置 } & \text { 茂 } & \text { 弘 } & \text { 丹羽金一 郎 } & & & \end{array}$

Clinicostatistical Observation on Jaw Deformities at the Department of Orthodontics, Asahi University Hospital

Maki Kitahara, Masao Kishimoto, Toshimitsu NiI, TOSHIYa NOMURA, YUya NAKAMURA, SHIN-ICHI INUZUKA, SHIGEHIRo HIOKI and Kin-ICHIRO NIWA

\begin{abstract}
A clinical evaluation study was performed on, and a questionnaire was administered to, patients with jaw deformities in the Department of Orthodontics at Asahi University Hospital, from April 1990 to August 2000. The findings were as follows: 1) Numbers of new patients tended to increase annually, with a male: female ratio of $1: 1.5$. 2) The age of new patients ranged from 7 to 42 years, with a mean of 19.9 years. 3) Regarding the geographical distribution of new patients, the majority were from Gifu prefecture $(81.3 \%)$, followed by Aichi $(10.0 \%)$ and Shiga prefectures $(6.0 \%)$. 4) Mandibular prognathism was the most frequently $(81.6 \%)$ observed type of jaw deformity. A rate of $67.5 \%$ of the patients demonstrated mandibular protrusion according to Slavicek's
\end{abstract}

\section{緒言}

近年, 咬合ならびに顔貌の審美観に対する認識が高まり, これらの改善を目的として矯正歯科を受診する患者が増加 している。この中には, 顎変形症として顎矯正手術を併用 する症例も少なくない。また, 1990 年に高度先進医療の 適用により外科的矯正治療に対して健康保険が導入されて 以来，外科的矯正治療を希望する患者は増加傾向にある。 classification, and $88.3 \%$ were classified as skeletal Class III type according to Sugawara's classification. 5) Missing teeth except for congenital tooth absence or third molar were observed in $24.7 \%$ of patients. 6) Prevalence of TMJ disorders was $23.1 \%$. 7) Items were investigated by inclusion in a questionnaire given to 70 patients with jaw deformities (males 15, females, 55 ; teenagers, 23 ; those in their 20s, 40 ; and those in their $30 \mathrm{~s}, 7)$. Results were as follows: Patients and their families tended to display dentfacial deformity; about $40 \%$ of patients had some complex from childhood, and many patients tended to display some habits in childhood.

Key words: jaw deformity (顎変形症), clinicostatistical observation (臨床統計), questionnaire ( ンケート)

[Received Jul. 15, 2002]

これらの背景の中でその現状を調査し把握することは，今 後の矯正歯科臨床や地域医療への貢献につながるものと考 えられる。

そこで, 朝日大学歯学部附属病院矯正歯科における顎変 形症患者を対象に臨床統計的観察を行った。また, 来院ま での経緯を把握するため, 上記顎変形症患者のうち回答の 得られた 70 名に対して, 小, 中学生期の咬合状態を中心 にアンケート調査を実施したので，その概要を報告する。 


\section{対象および方法}

1990 年 4 月から 2000 年 8 月までの 10 年 5 力月間に, 当 科において顎変形症と診断された 299 名（先天異常者を除 く）を対象にアンケートを含めた以下の 9 項目について調 查検討を行った。

1）年度別推移および男女比

2) 年齢別患者数

3）患者の居住地区

4) 臨床診断名別症例数

診断には正面·側面頭部 X 線規格写真, 口腔模型, 顔

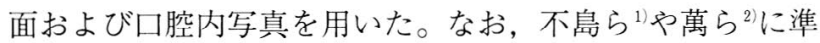
じて，正面頭部 X 線規格写真より CG（鷂冠基部）と ANS （前鼻棘）とを結ぶ CG-ANS plane を顔面正中線とし，こ れと ANS-Menton とのなす角度が $2^{\circ}$ 以上を下顎側方偏位 のある者とした。

5) Slavicek 分類 ${ }^{3}$

$\mathrm{FH}$ 平面に対して Nasionから垂直に降乃した

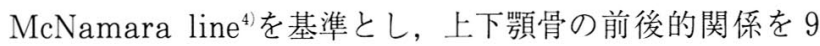
タイプに分類した。上顎は $\mathrm{A}$ 点,下顎は Pogonionを基準 点とした。なお，McNamara ${ }^{4}$ は A 点は McNamara line と一定の関係を保ち, Pogonion は前方へ移動するため成 長変化を考慮してオトガイの位置を判定する必要があると 述べていることから，根津ららによる方法を用いて当該年 齢に応じて Pogonion を補正し評価した。

6）顔面骨格夕イプの分類

顔面骨格タイプを营原 ${ }^{6} の$ 方法を用いて分類した。前後 的要因は ANS と Pogonionの前後的位置関係より skeletal Class I, skeletal Class II おうびskeletal Class III （以後 I 型，II 型，且型と称する）に，また垂直的要因は, Pogonionの上下的位置関係より Average face, Short face およびLong face (以後 A type, S type, L type と 称する）に分類し，各々を組み合わせて 9 種の顔面骨格型 に分類した。

7）喪失歯の有無

来院時既に咬失していた歯の有無（先天性欠如歯，第三 大曰歯を除く）を調べた。

8）顎関節症状の有無

初診時に扔ける顎関節症の 4 症状（顎関節雑音, 顎関節 部疼痛, 咀嚼筋痛揖よび開口障害）について単独あるいは 複合症状の有無を調査した。また, 雑音ならびに疼痛は, 患者の自覚症状にもとづき，問診および触診により診査し た。開口障害は, 最大開口量 $35 \mathrm{~mm}$ 以下と定義した。

9）アンケート

顎矯正手術を既に終了あるいは待機中の顎変形症患者に
対してアンケートを行い，回答が得られた 70 名（男性 15 名, 女性 55 名；10 代 23 名, 20 代 40 名, 30 代 7 名）に ついて受診までの調査を行った。

\section{結果}

1）年度別推移および男女比

1990 年 4 月から 2000 年 8 月までの 10 年 5 カ月の間に当 科で顎変形症と診断された患者は 299 名で, 年間平均症例 数は約 29 例, 全矯正患者数に対する割合は $11.0 \%$ であっ た。

患者数は 1997 年まで増加傾向を示し 1998 年に隇少する が，その後增加傾向にあった。また，男女比は男性 119 名 (39.8\%)，女性 180 名（60.2\%）で1：1.5 と女性の比率が 高かった。なお，1994 年まで 1：2 であった男女比は, 1995 年以降 $1: 1.2$ と男性の比率が増加した（Fig. 1)。

\section{2） 年齢別患者数}

初診資料採得時年齢は 7 歳から 42 歳の間に分布し, 平 均年齢は 19 歳 9 力月（男性平均 20 歳 1 力月，女性平均 19 歳 7 カ月) であり, 全体の $69.0 \%$ が 15 歳から 24 歳の間に 分布していた。女性は男性に比へ，やや低年齢上り来院し ているものの, 男女とも 10 代後半をピークに広範囲に分 布していた（Fig. 2)。

3）来院患者の居住地に関する調査

県・地域別にみた患者数は, 県内在住者が 243 例 $(81.3 \%)$ を占め，ついで愛知県 30 例 $(10.0 \%)$, 滋賀県 18 例 $(6.0 \%)$, 福井県 3 例 $(1.0 \%)$ であった。岐阜県下で は, 病院から半径 $10 \mathrm{~km}$ 圈内（岐阜市, 本巣郡, 大垣市, 羽島市など） 165 例 $(55.2 \%$ )，10～15km 圈内（揖斐郡， 各務原市など） 35 例（11.7\%)，15km 以上（山県郡，養

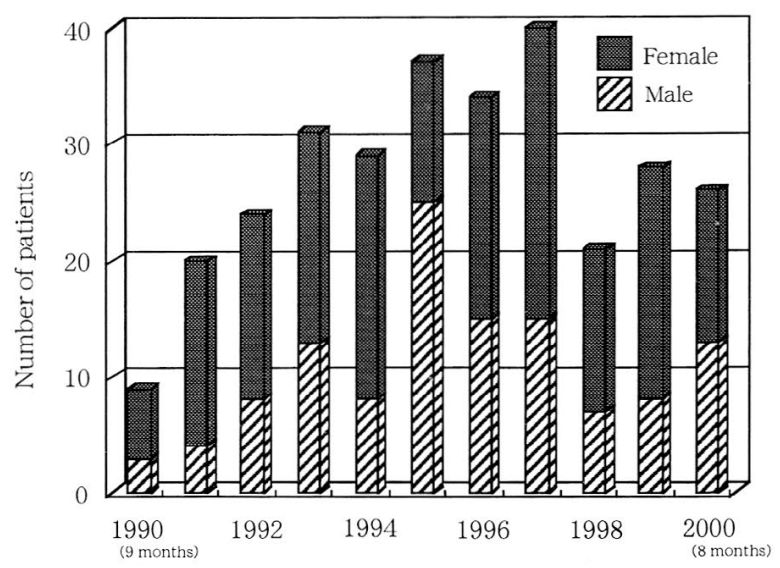

Fig. 1 Distribution of the patients in each year during recent 10 years.

The annual average: 29 years old. 


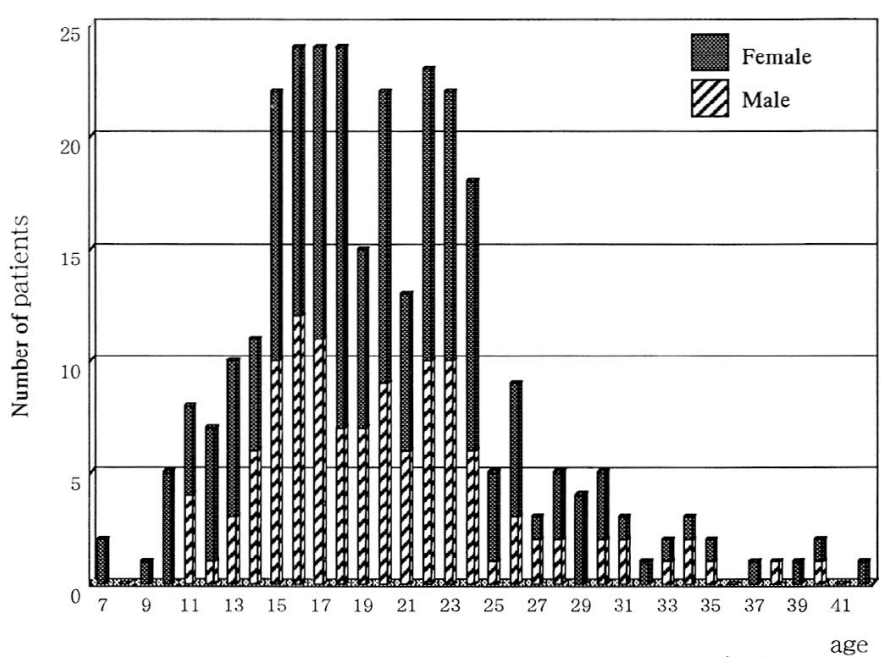

Fig. 2 Age and sex distribution of the patients. The age of the patients ranged from 7 to 42 and the male: female ratio was $1: 1.5$.

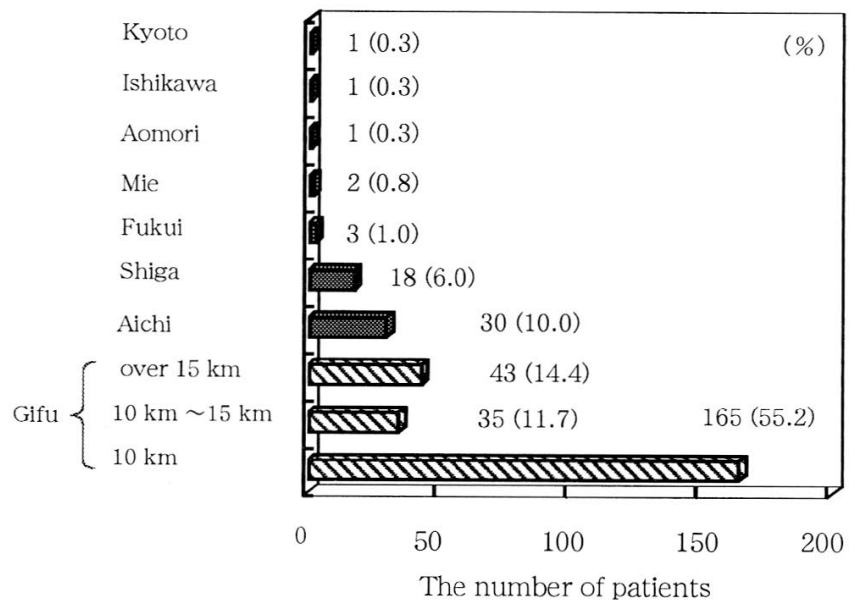

Fig. 3 Regional distribution of jaw deformity patients. Most of the patients ( $81.3 \%)$ came from Gifu Prefecture.

老郡など） 43 例 $(14.4 \%)$ であった（Fig. 3)。

\section{4) 不正咬合分類}

診断名別症例数の割合は，「下顎前突単独症例」が最も 多く全体の $34.8 \%$ を占め, ついで「下顎前突・下顎側方 偏位」が $24.1 \%$ ，「下顎前突・開咬」が $19.7 \%$ と続いた。 また，「下顎前突 · 開咬 ·下顎側方偏位」が $3.0 \%$ と, 単 独あるいは他の症状との併発も含めて「下顎前突症」が全 症例の $81.6 \%$ あった。一方,「上顎前突単独症例」は $1.7 \%$ ，「上顎前突・開咬」が $0.7 \%$ と低い割合にとどまっ た (Table 1)。

5) Slavicek 分類 ${ }^{3}$
Table 1 Diagnosis of jaw deformity patients.

\begin{tabular}{cr}
\hline Diagnosis & Number of patients $(\%)$ \\
\hline Mandibular prognathism & $104(34.8)$ \\
+ Mandibular asymmetry & $72(24.1)$ \\
+ Open bite & $59(19.7)$ \\
+ Mandibular asymmetry & \\
+ Open bite & $9(3.0)$ \\
Open bite & $21(7.0)$ \\
Mandibular asymmetry & $27(9.0)$ \\
Maxillary prognathism & $5(1.7)$ \\
+ Open bite & $2(0.7)$ \\
\hline
\end{tabular}


「上顎標準型・下顎前突型 $(\mathrm{N} / \mathrm{P})\rfloor$ が $38.1 \%$ と最も多く， ついで「上顎後退型・下顎前突型 $(\mathrm{R} / \mathrm{P})\rfloor$ が $16.7 \%$ ，「上 顎前突型・下顎前突型 $(\mathrm{P} / \mathrm{P})\rfloor$ が $12.7 \%$ と，全症例の 67.5\%に下䫈突出型が含まれていた。さらに，「上顎後退 型・卜顎後退型（R/R)」10.7\%,「上顎後退型・下顎標準

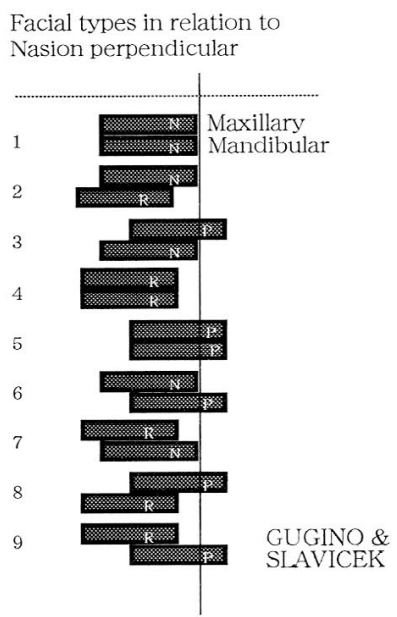

\begin{tabular}{llr} 
Classification & \multicolumn{1}{c}{$\begin{array}{r}\text { Number of } \\
\text { patients (\%) }\end{array}$} \\
\hline 1. & $\mathrm{N} / \mathrm{N}$ & $21(7.0)$ \\
2. & $\mathrm{N} / \mathrm{R}$ & $14(4.7)$ \\
3. & $\mathrm{P} / \mathrm{N}$ & $2(0.7)$ \\
4. & $\mathrm{R} / \mathrm{R}$ & $32(10.7)$ \\
5. & $\mathrm{P} / \mathrm{P}$ & $38(12.7)$ \\
6. & $\mathrm{N} / \mathrm{P}$ & $114(38.1)$ \\
7. & $\mathrm{R} / \mathrm{N}$ & $28(9.4)$ \\
8. & $\mathrm{P} / \mathrm{R}$ & $0(0.0)$ \\
9. & $\mathrm{R} / \mathrm{P}$ & $50(16.7)$ \\
\hline
\end{tabular}

Fig. 4 Slavicek's classification ${ }^{3)}$.

Maxillary/Mandibular

$\mathrm{N}$ : neutral $\mathrm{P}$ : protrusion $\mathrm{R}$ : retrusion
型 $(\mathrm{R} / \mathrm{N}) 」 9.4 \%$ が続いた（Fig. 4)。

6) 顔面骨格タイプの分類

顔面骨格型を 9 型に分類した結果,「正型，L type ( IIL)」 が $61.5 \%$ と最も多く，ついで「㘞型，A type ( II A)」が $18.8 \%$,「正型, S type (IIS)」が $8.0 \%$ となり, 全症例の 88.3\%が「而型」であった。「I型」では A type, S type ならびにL typeそれぞれ同率であったが，「II型」では $\lceil\mathrm{L}$ type」7.0\%,「A type」1.4\%,「S type」0.3\%であっ た。また，全症例のうち「L type」は $69.5 \%$ 占め,「A type」は $21.2 \%$,「S type」9.3\%であった（Fig. 5)。

7) 垜失歯の有無

来院時, 既に永久歯 (先天性欠如歯, 第三大臼歯を除く) に慗失がみられた患者は 74 名 $(24.7 \%)$ ，歯数 135 本であっ た。

部位別では，上下顎前歯部 7 名；9 本 $(6.7 \%)$ 上下顎犬 歯 6 名；8 本 $(5.9 \%)$ ，上下顎小臼歯部 26 名；42 本 (31.1\%) および上下顎大臼歯部 35 名； 76 本 (56.3\%) で あった（Table 2)。

8）顎関節症状の有無:

顎変形症患者全体における顎関節症状有症率は 69 名 (23.1\%) であり，男女別では男性 30 名 (25.2\%)，女性 39 名 $(21.7 \%)$ であった。不正咬合別顎関節症状有症率でみ

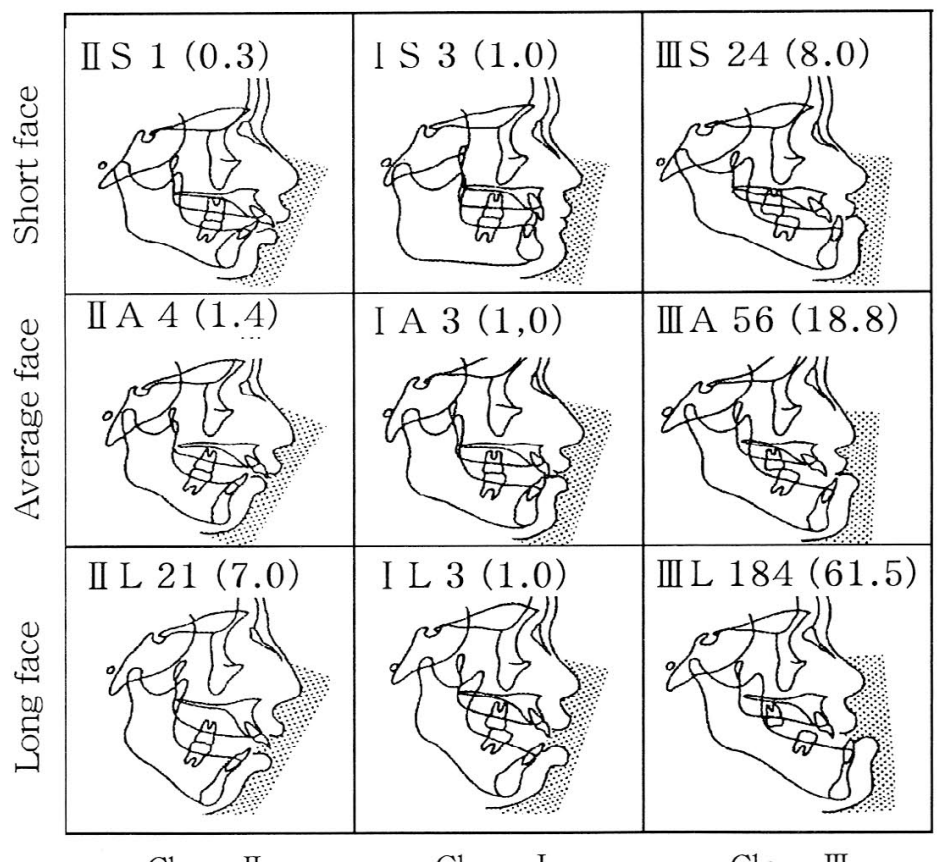

Class II

Class I

Class III

Fig. 5 Facial types according to Sugawara's classification ${ }^{6}$.

I : skeletal Class I S: short face type

II : skeletal Class II L: long face type

III : skeletal Class III A: average face type 
ると，開咬を伴う上顎前突 2 症例中 2 例 $(100 \%)$ ，下顎側 方偏位 27 症例中 9 例 $(33.3 \%)$ ，下顎前突 104 症例中 32 例 $(30.8 \%)$ の順に多かった（Table 3)。

症状では, 男女ともに雑音のみ, 雑音と疼痛の順で多かっ たが，複合症状は女性に多くみられた（Table 4)。

Table 2 Kinds of missing teeth (without congenital missing tooth and third molar).

Kinds of teeth Number of teeth (\%) Number of patients

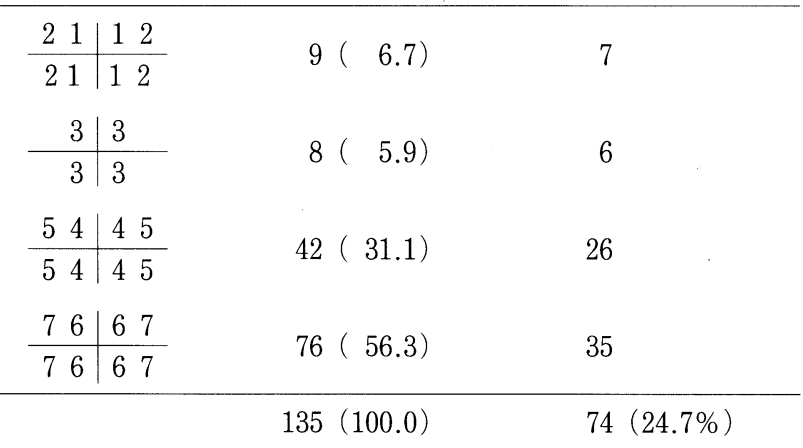

9) アンケート結果

アンケートの内容とその結果を Table 5 に示す。

40.0\%が定期的に歯科医院にかかっていたと答え，齟蝕 が多かったと回答したのは $54.3 \%$ 小学生時が $70.0 \%$ で あった。また $28.5 \%$ はなんらかの矯正治療を受けており， 小学生時が $68.4 \%$, 中学生時が $31.6 \%$ であった。その当時 の歯並びは,下顎前突および交叉咬合がともに $7.1 \%$ と多かっ た。習癖の有無については $77.9 \%$ が，さらに鼻疾患につ いては $28.6 \%$ あったたと回答しており，習癖は多い順に， 煩杖をつく $(22.1 \%)$ ， 口呼吸 $(20.9 \%)$ ，指しゃぶり (10.5\%) となった。口腔機能に関しては, 咀嚼では 40.0 $\%$, 発音では $34.3 \%$ が困難があったと回答し, 顔が非対 称だと感じていたのは $40.0 \%$ あった。外傷の既往は $15.7 \%$ にられた。また, 顎関節に痛みや音がすることが あったかという問いには $42.9 \%$ があったと答え, 中学生 時に多かった。家族が患者と同じような咬み合わせをして いると答えた者は $41.4 \%$ で，うち $50.4 \%$ が両親と同じで あると回答した。胎生期における母胎の異常は $2.9 \%$ に, 出生時の異常は $10.0 \%$ にられた（Table 5)。

Table 3 Prevalence of TMJ disorders.

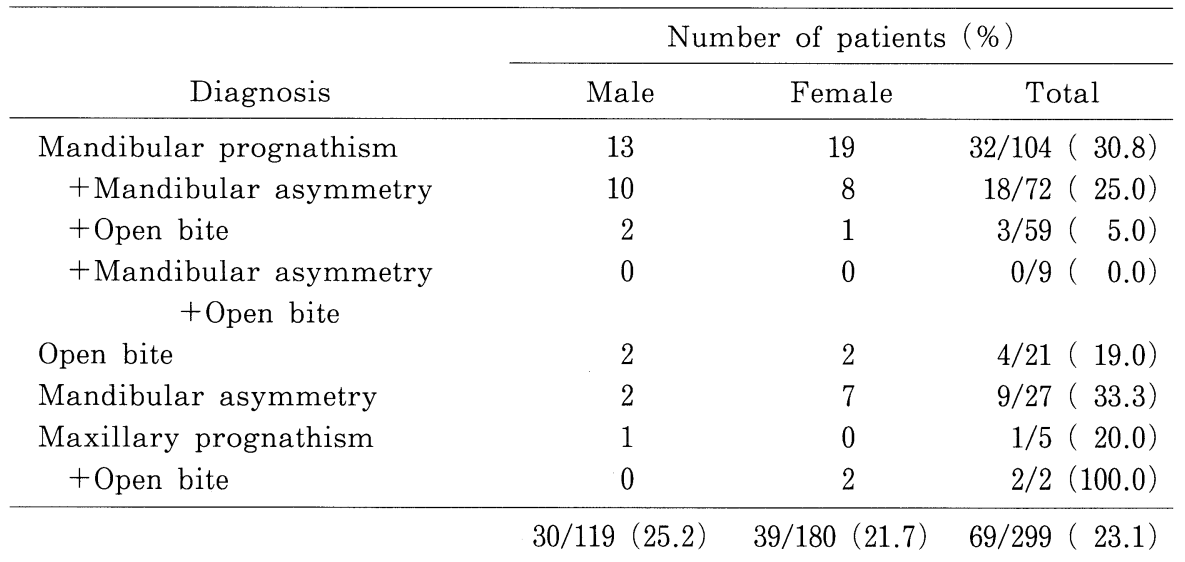

Table 4 Distribution of the symptoms of TMJ disorders.

\begin{tabular}{|c|c|c|}
\hline \multirow[b]{2}{*}{ Symptoms } & \multicolumn{2}{|c|}{ Number of patients (\%) } \\
\hline & Male & Female \\
\hline TMJ sound $(\mathrm{S})$ & $18(60.0)$ & $16(41.0)$ \\
\hline Fatigue or discomfort of the jaw muscle (M) & $3(10.0)$ & $5(12.8)$ \\
\hline Pain in orofacial region or jaw movement $(P)$ & $3(10.0)$ & $2(5.1)$ \\
\hline Difficulties in jaw movement $(\mathrm{J})$ & $1(3.3)$ & $2(5.1)$ \\
\hline $\mathrm{P}+\mathrm{C}$ & $5(16.7)$ & $12(30.8)$ \\
\hline $\mathrm{P}+\boldsymbol{J}$ & $0(0.0)$ & $2(5.1)$ \\
\hline Total & $30(100.0)$ & $39(100.0)$ \\
\hline
\end{tabular}


Table 5 Items of questionnaire and result given to 70 patients with jaw deformities (male 15, female 55 ; teenagers $n=23,20 \mathrm{~s} n=40,30 \mathrm{~s} n=7$ ).

E. = elementary school J.= junior high school

1. Did you see your dentist regularly?

（歯科医院に定期的にかかっていましたか？）

(Yes. $40.0 \% \rightarrow$ E. $68.4 \%$ J. $31.6 \%$ ) (No. $60.0 \%$ )

2. Did you suffer from many cavities during childhood? （子供の頃虫歯は多かったですか？）

(Yes. $54.3 \% \rightarrow$ E. $70.0 \%$ J. $30.0 \%$ )（No. $45.7 \%$ )

3. Did you receive any orthodontic therapy in that time? （その頃歯並びを治しましたか？）

(Yes. 28.5\% $\rightarrow$ E. $68.4 \%$ J. 31.6\%) (No. 71.5\%)

4. What shape were your teeth in? （歯並びはどうでしたか?）

· No problem (8.6\%) · Unknown $(65.6 \%) \cdot$ malocclusion $(25.8 \%)$

(問題なし)

(わからない) (不正咬合)

$\rightarrow$ Prognathia $(2.9 \%)$

(上顎前突)

Progenia (7.1\%)

Bimaxillary protrusion (2.9\%)

Crowding $(2.9 \%)$

(叢生)

(下顎前突)

(上下顎前突)

Open bite $(2.9 \%) \quad$ Cross bite $(7.1 \%)$

5. Did you have any of the following habits? * the multiple answer

（口に何か癖がありましたか？）（Yes. 77.9\%）（No. 22.1\%）

$\rightarrow \cdot$ Tongue thrusting $(7.2 \%) \cdot$ Lip sucking or Lip biting $(7.2 \%)$

(舌癖)

（唇を吸う，または噛む）

- Mouth breathing (20.9\%) - Resisting chin in hands $(22.1 \%)$

(口呼吸)

（煩づえをつく）

· Bruxism (7.2\%) · Thumb sucking (10.5\%)

(歯ぎしり)（指しゃぶり）

- Others (3.5\%) · Nothing (22.1\%)

(その他) (なし)

6. Did you experience any rhinitis in your childhood? （鼻が悪かったですか?）

(Yes. $28.6 \% \rightarrow$ E. $85 \%$ J. 15\%) (No. $71.4 \%)$

7. Did you ever have any difficulties eating?

（食事を食べにくいと感じたことがありましたか？）

(Yes. $40.0 \% \rightarrow$ E. $50.0 \%$ J. $50.0 \%$ ) (No. $60.0 \%$ )

8. Did you ever have any problems pronouncing words?

（発音しにくいと感じたことがありましたか？）

(Yes. $34.3 \% \rightarrow$ E. $54.2 \%$ J. $45.8 \%$ ) (No. 65.7\%)

9. Did you ever feel your face is asymmetric?

（顔が非対称だと感じたことがありましたか？）

(Yes. $40.0 \% \rightarrow$ E. $85.0 \%$ J. $15.0 \%$ ) (No. $60.0 \%$ )

10. Have you ever suffered facial or jaw trauma during childhood?

(顔やあごにけがや事故を経験したことがありましたか? )

(Yes. $15.7 \% \rightarrow$ E. $45.5 \%$ J. $54.5 \%$ ) (No. $84.3 \%$ )

11. Were there any pains or sounds at the site of the jaw? （アゴの関節が痛かったり，音がすることがありましたか?）

(Yes. $42.9 \% \rightarrow$ E. $23.3 \%$ J. $76.7 \%$ ) (No. $57.1 \%$ )

12. Have you ever had any pain or numbness in your facial muscles? (顔の筋肉が痛かったことがありましたか?）

(Yes. $13.0 \% \rightarrow$ E. $0.0 \%$ J. $100.0 \%$ ) (No. 87.0$)$

13. Dose anyone in your family suffer from any symptoms of jaw deformity or abnormal occlusion like you? (家族で同じようなかみ合わせの人がいますか? )

(Yes. $41.4 \% \rightarrow$ Parents $50.4 \%$ Sister or brother $27.6 \%$ Others $6.8 \%$ ) (No. 58.6\%)

14. Did your mother suffer from any illness during her pregnancy with you? （あなたがお腹にいる時，お母さんに異常がありましたか？）

(Yes. 2.9\%) (No. 97.1\%)

15. How was your birth, Natural or Assisted?

(Was your birth Natural or Assisted?)

（あなたの出生時の状態はどうでしたか？）

a. Normal $(82.9 \%)$ b. Abnormal $(10.0 \%){ }^{*}$ Cesarean section $\cdots \quad$ c. Unknown $(7.1 \%)$ 


\section{考察}

\section{1. 統計的観察}

顎変形症患者に対する矯正治療に健康保険が導入されて 以来, 社会的認識および患者のニーズと相まって, 患者数 は年々増加する傾向がみられたが, 1998 年に減少し, そ の後増加するものの緩やかなものとなっていた。これは, 社会的不況 ${ }^{7)}$ や 1997 年に健康保険被用者の負担が 1 割か ら 2 割に引き上げられたことから歯科の受診率が低下し

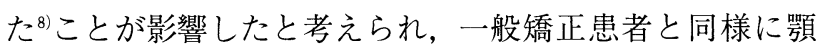
変形症の患者数も社会的経済状況に大きく左右されると推 察された。

男女比は $1: 1.5$ と諸家の報告 ${ }^{-11)}$ と同様に女性の受診率 が高く，女性の審美改善への関心の高さを示しているもの の, 1995 年以降では男性の比率が増加しており, 他施設 の報告 ${ }^{12,13)}$ と同様に男性の矯正治療や審美改善への関心が 高まっている傾向にあると考えられた。

初診時年齢は 7 歳から 42 歳に分布し, 15 歳から 24 歳 が最も多く全体の約 $69 \%$ を占めており, 平均年齢は 19 歳 9 力月（男性平均 20 歳 1 力月, 女性平均 19 歳 7 力月）で

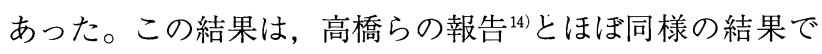
あった。

来院患者の居住地域は岐阜県が圧倒的に多く $81.3 \%$ を 占め, ついで隣県の愛知県 $10.0 \%$, 滋賀県 $6.0 \%$ の順であっ た。さらに, 県下では大学から半径 $10 \mathrm{~km}$ 圈内（岐阜市, 大垣市，本巣郡など）が $55.2 \%, 10 \mathrm{~km} \sim 15 \mathrm{~km}$ 圏内（揖 斐郡，各務原市など） が $11.7 \%$ と, 半径 $15 \mathrm{~km}$ 圈内に 66.9 \%の者が居住しており, 他の報告 ${ }^{15)}$ と同様に, 通院時間が 深く関係している結果となった。

不正咬合の臨床診断名別内訳では, 下顎前突症が「単独 および複合症例」も含め全症例の $81.6 \%$ であったのに対 して，「上顎前突単独症例」は $1.7 \%$,「上顎前突・開咬」 が $0.7 \%$ と低い割合であった。これらは水本ら ${ }^{15)}$ の報告や 滝本 ${ }^{16)}$ の報告と同結果となった。さらに, Slavicek 分類で は $67.5 \% に 「 下$ 顎突出型」がみられ, 菅原の分類でも $88.3 \%$ 「正型」であった。

一方, 上顎の前後的位置関係を Slavicek 分類よりみる

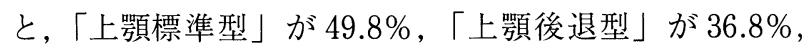
「上顎前突型」が $13.4 \%$ という結果となり，当科における 顎変形症患者で上顎骨に問題があるものは約 $50 \%$ で,その うち $40 \%$ が上顎後退型となり, 高木ら ${ }^{17)}$ とほぼ同様な結果 であった。

菅原の分類より垂直的な関係についてみると，「L type」 は全症例の $69.5 \%$ を占め,「A type」は $21.2 \%$,「S type」 が9.3\%であった。「I型」では 3 type とも同率であった
が,「II型」では「L type」が7.0\%,「A type」1.4\%, $\lceil S$ type」0.3\%の順となり，上下顎骨の前後的関係のみ ならず，下顔面での垂直的な関係の改善も重要であると考 えられた。

衰失歯の有無については, 平成 11 年度歯科疾患実態調 査報告 ${ }^{18)}(20 \sim 24$ 歳で $12.6 \%)$ と比較すると, 1 本以上の 韍失歯がある患者は $24.7 \%$ と明らかに多かった。さらに 部位別岥失歯数では, 同実態調査報告 ${ }^{18)}$ によると上下顎大 臼歯の生存率が 20 代前半でほぼ $100 \%$ ，40 代前半で約 80 \%であり, 今回の結果において全喪失歯における大臼歯の 喪失が $56.3 \%$ あったたことから，大臼歯と顎変形症の関 連が推察された。臨床において, 多数歯欠損や歯冠架橋補 緅歯を伴う症例にはしばしば遭遇することから, 今後の治 療においては多くの関連診療科と連携した包括的歯科治療 を行う必要性が示唆された。

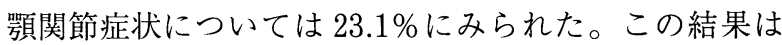
加藤ら ${ }^{19)}(77.6 \%)$, 佐藤ら ${ }^{20)}(53.3 \%)$ と比較すると低く, 白石ら ${ }^{21)}(21.9 \%)$ と同様の頻度であった。また男女別の 有症者率は男性 $25.2 \%$, 女性 $21.7 \%$ であった。対象とな る集団, 年齢, 調査方法等の条件が異なるため単純に比較 することは難しいが, 顎変形症患者における顎関節症の発 症率は, 他の報告 ${ }^{19,20)}$ と同様に当科でも性差はない傾向に あった。これらの原因の一つとしては, 藤崎ら ${ }^{222}$ が述べて いるように, 顎変形症患者が咬合異常や審美性の改善を主 訴として来院することが考えられる。症状については, 雑 音および疼痛といった複合症状が女性に多く, 加藤ら ${ }^{23)}$ 報告と同様に，女性の方が重篤な症状を示す傾向にあった。 さらに，不正咬合別の有症状者率は開咬を伴う上顎前突 2 症例中 2 例 $(100 \%)$, 下顎側方偏位 27 症例中 9 例 $(33.3 \%)$, 下顎前突 104 症例中 32 例 $(30.8 \%)$ の順に多 く, 不島ら ${ }^{24)}$ とほぼ同様の結果となった。

2. アンケートについて

1) 歯科治療および矯正治療既往歴

全体の $40.0 \%$ が定期的に歯科医院に通っていた。齨蝕 は $54.3 \%$ が多かったと回答し, 吉田ら ${ }^{25)}$ よりやや少ない結 果であった。なんらかの矯正治療を受けた経験のある患 者は $28.5 \%$ で，その約 70\%が小学校時に経験しているこ とから, 既に混合歯列期より歯列不正や顎の異常などを発 症していたと考えられる。しかしながら，「その頃の歯並 びはどうであったか」という質問に対し，「問題なし」 (8.6\%) や「記憶にない」(65.6\%)が全体の約 74\%であり， 自身の症状に対する認識は低かったと考えられる。また, 習癖については約 78\%があったと回答していた。吉田ら ${ }^{25)}$ は, 顎変形症患者における幼少児期の齲蝕の多寡, 矯正治 療歴の有無および口腔習癖は, 顎変形症を伴わない対照群 
と比較して有意に多かったと報告しており，本調査でも同 様な傾向が見られた。

2）患者の口腔機能および顔貌に対する認識

咀嚼では $40.0 \%$ が, 発音では $34.3 \%$ が小, 中学生時に 違和感があったと回答しており，不正咬合によるこれらの 障害が早期に発現しているものと思われた。正貌の非対称 については $40.0 \%$ が小, 中学生時にかけてすでに認識し ていた。これは, 成長による症状の顕著化と, 自己の審美 性への関心の現れであると考えられた。土川 審美性にかかわる cathexis が青年期に増大すると報告し ており, 外科的矯正治療において審美的障害の改善の意義 は大きいと考えられた。

3）外傷·顎関節症状の既往

アンケートでは，外傷の既往は $15.7 \%$ であったが，顎関 節に違和感があったと $42.9 \%$ が答えており, 今回の臨床 統計における顎関節症の有症率 $(23.1 \%)$ の 2 倍近くに達 していた。この差は, 患者自身による主観的な判断と, 第 三者による客観的な判断の違い, 対象者の数, 男女比など の違いによるものと考えられた。

\section{4) 遺伝的要因}

「家族で似たようなかみ合わせをしている」と答えたの は $41.4 \%$ であり, そのうち両親と答えたのは $50.4 \%$ であっ たことから, 顎変形症の発症の遺伝的要因の影響が示唆さ れた。また吉田ら ${ }^{25}$ は顎変形症患者は胎生期における母胎 の異常や異常分婏が見られる傾向があったと報告している が, 本アンケートでも母体の異常は $2.9 \%$, 出生時の異常

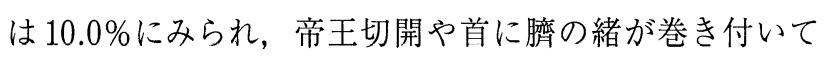
いたというものであった。

\section{結語}

1990 年 4 月から 2000 年 8 月までの 10 年 5 カ月間に朝日 大学歯学部附属病院矯正歯科において顎変形症と診断され た患者 299 名について臨床統計的検討を行うとともに, 同 患者に対するアンケート調査で回答のあった 70 名につい て調査を行い以下の結果を得た。

1）年度別患者数は全体的に増加傾向にあり, 男女比は $1: 1.5$ であった。

2）初診時年齢は 7 歳から 42 歳の間に分布しており, 平 均年歯令は 19 歳 9 カ月であった。

3）初診患者居住地域分布は, 岐阜県が $81.3 \%$ あり, ついで愛知県, 滋賀県の順であった。

4）臨床診断名別症例数では, 単独および併発を含めて 「下顎前突症例」が $81.6 \%$ と最も多かった。

5）S Slavicek 分類では「上顎標準型・下顎前突型 $(\mathrm{N} / \mathrm{P})\rfloor$ $38.1 \%$,「上顎後退型・下顎前突型（R/P)」16.7\%の順に
多かった。

6）顔面骨格夕イプの分類では「III 型 L type（ II L )」 が $61.5 \%$ と最も多かった。

7）丧失歯を有する患者は $24.7 \%$ であり，大臼歯部に多 く見られた。

8）顎関節症有症率は $23.1 \%$ あった。

9）アンケート結果から, 患者らは, 小, 中学生時に自 身の口腔機能, 顔貌に対する高い意識をもっていたことが 判明した。さらに顎変形症について遺伝的要因や, 習癖の 関連性ならびに顎関節症の併発の可能性が考えられた。

\section{参考文献}

1）不島健持, 他：下顎側方偏位症例の形態学的特徴およ び顎関節症状の発現一正貌頭部 X 線規格写真による 分析一, 日矯歯誌, $48: 322-328,1989$.

2）萬 健一, 他：骨格性下顎前突症患者における咀嚼時 下顎頭運動の解析, 日顎変形誌, 10(1) : 6-10, 2000.

3) 根津 浩, 他編集 : 歯科矯正学 バイオプログレッシ ブ診断学, ロッキーマウンテン・モリ夕, 東京, 1984, 68 頁.

4) McNamara. J. A. : A method of cephalometric evaluation, Amer. J. Orthod, 86(6) : 449-469, 1984.

5) 根津 浩, 他編集：歯科矯正学 バイオプログレッシ ブの臨床，ロッキーマウンテン・モリ夕，東京，1988, 48-51 頁.

6）菅原準二：下顎骨の形と顎顔面骨格型との関係につい て, 日矯歯誌, $40: 32-46,1981$.

7）矢部洋三，他：新訂現代日本経済史年表，第一版，日 本経済評論社，東京，370-453，2001.

8）厚生省: 種類別受診率の伸び率, 平成 9 年度「医療費 の動向」, 1998.

9）柚木大和, 他 : 大阪歯科大学口腔外科学第 2 講座にお ける 11 年間の顎矯正手術の臨床統計的観察，日顎変 形誌, $9: 51-56,1999$.

10）宮手浩樹，他：当科過去 7 年間における顎矯正手術の 臨床統計的観察，日顎変形誌， $7: 31-39 ， 1997$.

11）吉屋 誠, 他 : 顎矯正手術を施行した 305 名（314 例） の臨床統計的観察, 日顎変形誌, $6: 137-144,1996$.

12）伊藤率紀，他：矯正治療受療患者の年代推移に関する 実態調査, 近東矯歯誌, $24: 65-72,1989$.

13）山田 潔, 他 : 神戸大学口腔外科における顎矯正手術 施行例の臨床統計的観察, 日顎変形誌, $6: 105-114$, 1996.

14）高橋一郎，他 : 大阪歯科大学附属病院における顎変形 症患者の臨床統計的観察，日顎変形誌，5:184-189, 1995.

15）水本恭史，他：松本歯科大学病院矯正科開設後 15 年 間に来院した患者の実態調査一その 2 昭和 52 ～昭和 56 年一, 松本歯学, $14: 339-346,1988$.

16）滝本和男：顔面写真の研究（第一報）日本人と米国人 との比較, 口病誌, $19: 118-122,1952$.

17）高木豊明, 他 : 徳島大学歯学部付属病院矯正科におけ る顎変形症患者の臨床統計的観察，四国歯誌，11： 
225-231, 1999.

18）厚生労働省医政局歯科保健課編 平成 11 年度歯科疾 患実態調査報告, 東京, 2001, 財団法人口腔保健協会.

19）加藤嘉之, 他 : 顎変形症患者における顎関節症の統計 的観察, 日顎変形誌, $7: 40-48,1997$.

20）佐藤修一，他：顎変形症患者における顎関節症状の発 現状況について，日顎誌，5:8-16，1993.

21) 白石 芳, 他：顎変形症手術の前後における顎関節症 状の推移に関する臨床統計的観察, 日顎変形誌, 3 : 147-153, 1993.

22）藤崎 弘，他 : 不正咬合者における顎関節症に関する アンケート調査結果, 日顎誌, 5 : 320-333, 1993.
23）加藤嘉之, 他 : 顎関節症に関与する因子の検討一性別, 年齢, 関節可動性について一. 日顎誌, 10:71-80, 1998.

24）不島健持, 他：不成咬合者における顎関節症状の発現 一顎関節症の成立機転に関する一考察一. 日顎誌, 1 : 40-50, 1989.

25）吉田憲司, 他 : 顎変形症患者の疫学調査一質問紙法調 査を中心に一, 日顎変形誌，6：63-75，1996.

26）土川登志子 : 不正咬合にかかわる cathexis について, 日矯歯誌, $41: 343-354,1982$. 